\title{
IMMUNOLOGICAL COMPLICATIONS OF TRANSFUSION
}

\author{
Marcela Contreras, P L Mollison
}

\begin{tabular}{|c|c|c|}
\hline \multicolumn{3}{|c|}{$\begin{array}{l}\text { Immunological complications of blood } \\
\text { transfusion: }\end{array}$} \\
\hline Red cells & $\begin{array}{l}\text { Haemolytic reactions: } \\
\text { Immediate } \\
\text { Delayed }\end{array}$ & $\begin{array}{c}\text { Percentage } \\
\text { frequency } \\
0.02 \\
0.2\end{array}$ \\
\hline White cells & $\begin{array}{l}\text { Febrile reactions } \\
\text { Pulmonary infiltrates }\end{array}$ & $\begin{array}{r}5-10 \\
<0.01\end{array}$ \\
\hline Platelets & $\begin{array}{l}\text { Post-transfusion } \\
\text { purpura }\end{array}$ & $<0.01$ \\
\hline $\begin{array}{l}\text { Plasma proteins: } \\
\text { Native } \\
\text { Ingested }\end{array}$ & $\begin{array}{l}\text { Anaphylaxis } \\
\text { Urticaria }\end{array}$ & $<0.01$ \\
\hline
\end{tabular}

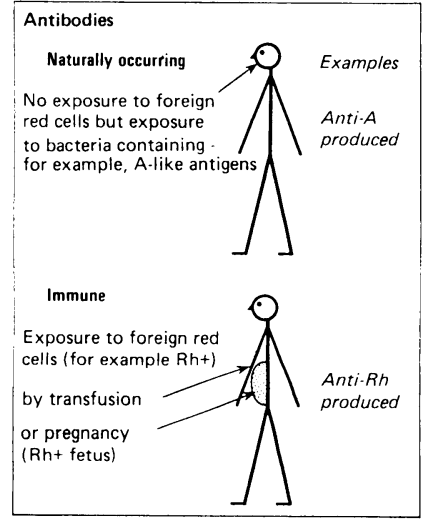

The transfusion of blood or its components can correct many deficiencies, even if only temporarily, and in most cases this effect can be achieved without any untoward effects. Nevertheless, incompatibilities of several kinds do occasionally cause trouble. Each blood cell has many different antigens on its surface, so the cells of a donor are virtually certain to contain antigens different from those of the recipient. In addition, the donor's plasma may contain proteins that are foreign to the recipient. Fortunately the transfusion of blood cells or plasma containing foreign antigens causes an immediate reaction only when the recipient's serum contains a corresponding antibody. In practice, severe reactions (caused, for example, by transfusion of incompatible red cells) are rare, whereas mild reactions (caused, for example, by reactions to foreign protein and characterised by urticaria) are common.

For two reasons antibodies to red cell antigens are the most important in blood transfusion. Firstly, the volume of red cells transfused is usually greater than that of white cells or platelets so that if incompatible red cells are transfused the consequences are comparatively severe. Secondly, antibodies evoked by transfusions in women of childbearing age may subsequently cause haemolytic disease in their offspring.

\section{Naturally occurring and immune antibodies}

Some antibodies are found in subjects who have never been exposed to foreign blood cells, and the most important of these so called "naturally occurring" antibodies are anti-A and anti-B. Most others are "immune" and arise only after transfusion, or after pregnancy, when small numbers of fetal red cells enter the maternal circulation and may immunise the mother to antigens that the fetus has inherited from the father. Anti-D of the Rh system (anti-RhD) is the most common immune blood group antibody.

\section{Reactions to incompatible red cells}

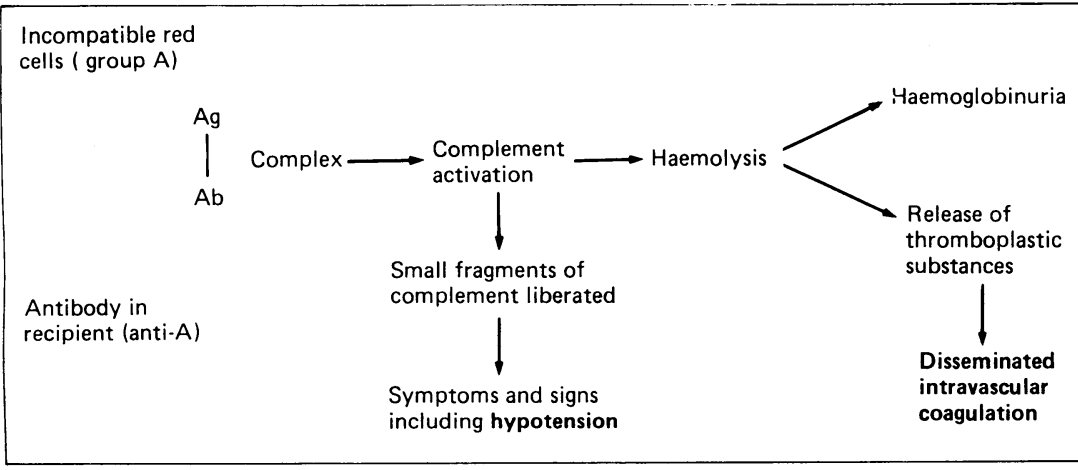

Most incompatible transfusions are caused not by serological errors but by giving blood to the "wrong" patient, that is, to a different patient from the one whose serum was tested before transfusion. The frequency with which incompatible transfusions are given is unknown, but their incidence is underreported; published estimates range from about $1 / 1000$ to $1 / 20000$ transfusions. 


\begin{tabular}{|c|c|c|}
\hline \multicolumn{3}{|c|}{ Immune red cell destruction } \\
\hline $\begin{array}{l}\text { Site of } \\
\quad \text { destruction }\end{array}$ & $\begin{array}{l}\text { Predominantly } \\
\text { intravascular }\end{array}$ & $\begin{array}{l}\text { Predominantly } \\
\text { extravascular }\end{array}$ \\
\hline $\begin{array}{c}\text { Characteristics } \\
\text { of antibodies }\end{array}$ & (Anti-A and B) & $\begin{array}{l}\text { Antibodies that do } \\
\text { not activate or } \\
\text { only partially } \\
\text { activate } \\
\text { complement } \\
\text { (Anti-Rh, anti-K, } \\
\text { anti-Jk, and } \\
\text { others) }\end{array}$ \\
\hline Symptoms & $\begin{array}{l}\text { Substernal pain, } \\
\text { lumbar pain, } \\
\text { restlessness }\end{array}$ & Nausea, shivering \\
\hline \multicolumn{3}{|l|}{ Signs: } \\
\hline Immediate & $\begin{array}{l}\text { Hypotension, } \\
\text { fever, } \\
\text { uncontrollable } \\
\text { bleeding }\end{array}$ & Fever \\
\hline Later & Haemoglobinuria & Jaundice \\
\hline
\end{tabular}

\section{Circumstances in which whole incompatible} transfusions given

Patient wrongly identified because:

- Unconscious (operation)

- Wristband removed during operation

- Human error

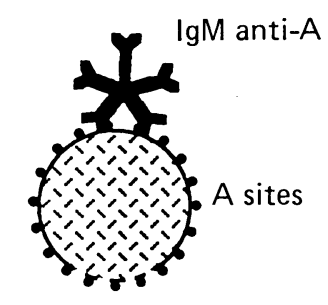

Red cell ruptures

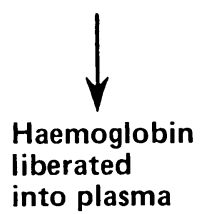

$\lg \mathrm{M}$ anti-A on binding to two adjacent $A$ sites activates whole of complement pathway (C1-9). C8, 9 make holes in red cell membrane.

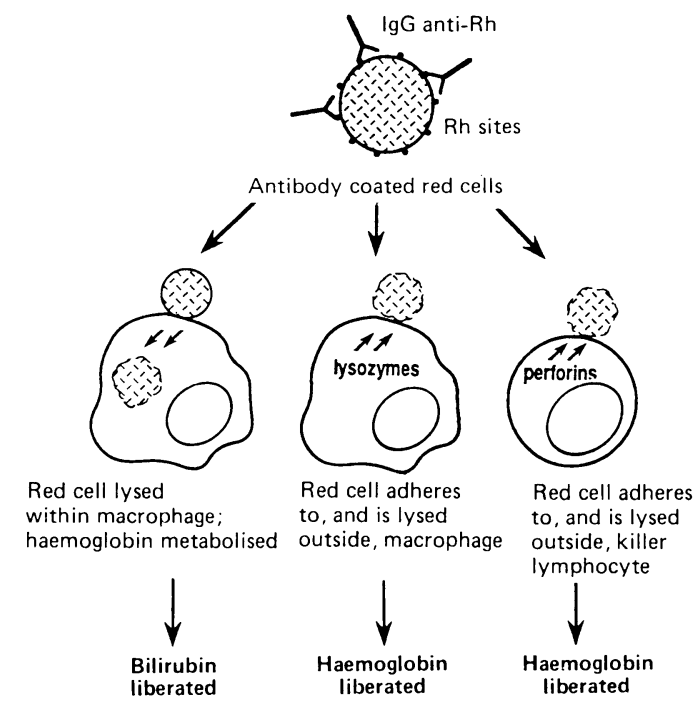

IgG anti-Rh does not activate complement. Red cell coated with antibody adheres to a macrophage or a killer lymphocyte and is either ingested and lysed or lysed at the cell surface.

\section{Immediate haemolytic transfusion reactions}

A haemolytic transfusion reaction means the occurrence of signs of increased destruction of red cells after a transfusion. Mild haemolytic reactions may be caused in various ways - for example, by transfusing blood that has been stored for too long - but severe haemolytic reactions are almost always caused by transfusing incompatible red cells (in most cases $\mathrm{ABO}$ incompatible).

The main reasons why $\mathrm{ABO}$ incompatibility plays so large a part are:

(1) Anti-A and anti-B are the most common blood group antibodies. They are present in the plasma of all subjects whose red cells lack the corresponding antigens. For example, a person of group $\mathrm{O}$ always has anti$\mathrm{A}$ and anti-B in the plasma.

(2) If a mistake is made in identifying a patient and the wrong blood is transfused (that is, blood that has been selected for a different patient) the chance (in a white subject) that it will be $\mathrm{ABO}$ incompatible is as high as one in three.

(3) Anti-A and anti-B are usually potent (especially in group $\mathrm{O}$ subjects) and by activating complement produce rapid lysis of incompatible red cells so that reactions to $\mathrm{ABO}$ incompatible blood are usually severe.

Nevertheless, mortality is probably less than $10 \%$.

Haemolytic reactions as a result of transfusing incompatible red cells may also be caused by the presence of any other red cell antibody active at $37^{\circ} \mathrm{C}$ in the recipient's blood. The next most common after anti- $\mathrm{A}$ and anti- $\mathrm{B}$ is anti$\mathrm{RhD}$. Rh antibodies do not activate complement, and reactions caused by $\mathrm{Rh}$ incompatibility are usually much milder than those caused by ABO incompatibility.

Features of haemolytic transfusion reactions that are the result of transfusion of $\mathrm{ABO}$ compatible blood are:

Circumstances - As the cause of most incompatible transfusions is failure to identify the recipient correctly, most are given in emergencies and in surroundings in which the patient is not well known to those who are attending to him. Thus most are given in operating theatres or intensive care units. Most patients who receive incompatible blood are unconscious at the time, so that there are no symptoms that might call attention to what is happening.

Mechanisms of red cell destruction - When $\mathrm{ABO}$ incompatible red cells are transfused - for example, donor group $\mathrm{A}$ and recipient group $\mathrm{O}$ - the incompatible antibody (anti-A in this case) immediately binds to the donor's red cells. The bound antibody activates complement leading to immediate lysis of donor red cells in the plasma. When the antibody is potent virtually all the transfused red cells may be lysed within the bloodstream. Many other blood group antibodies activate complement, but as a rule do so only partially, and the cells are not lysed but rather ingested by macrophages as they pass through the liver and spleen. Some antibodies - for example, anti- $\mathrm{Rh}$ - do not activate complement, and these also cause macrophages to remove coated cells.

Symptoms and signs - In the conscious patient the transfusion of even a few millilitres of $\mathrm{ABO}$ incompatible blood may cause symptoms within one or two minutes. The patient becomes restless and complains of a feeling of oppression that is often accompanied by substernal pain. He may also complain that his face is burning and he may have abdominal pain and may vomit.

In the unconscious patient the most important signs are hypotension and uncontrollable bleeding.

The main cause of the symptoms and of the hypotension is the release of the products of complement (C3a, C4a, and $\mathrm{C} 5 \mathrm{a}$ ) into the plasma. These are polypeptides with a molecular weight of about 20000 that cause contraction of smooth muscle; they also cause degranulation of mast cells leading to the release of vasoactive substances (bradykinin and serotonin). Bleeding is caused by disseminated intravascular coagulation, which is thought to be triggered by procoagulant substances released from red cell stroma after lysis and also - possibly - by the direct activation of the coagulation system by antigen-antibody complexes. 
Oliguria is common after the transfusion of $\mathrm{ABO}$ incompatible blood and is thought to be the result of changes in renal blood flow precipitated by hypotension, rather than haemoglobinuria. As soon as it is suspected that incompatible blood has been transfused the transfusion should be stopped, and an intravenous infusion of crystalloid solution should be started to maintain urinary output. Frusemide $80-120 \mathrm{mg}$ should be given intravenously. The labels on the transfused unit and on all relevant blood samples should be checked and the laboratory notified; this is particularly important because if the unit has been given to the wrong patient, the right unit may have been - or may be about to be-given to another "wrong" patient. If renal failure becomes established the advice of a renal physician should be sought as soon as possible.

Although severe symptoms may follow the transfusion of only a few millilitres of incompatible red cells in patients with potent anti-A and anti$B$, in patients with weak antibodies the transfusion of several units of $A B O$ incompatible blood may cause only trivial effects.

In $\mathrm{Rh}$ incompatibility fever is often the only sign of an adverse reaction, although jaundice is quite common and haemoglobinuria (not associated with renal failure) sometimes develops.

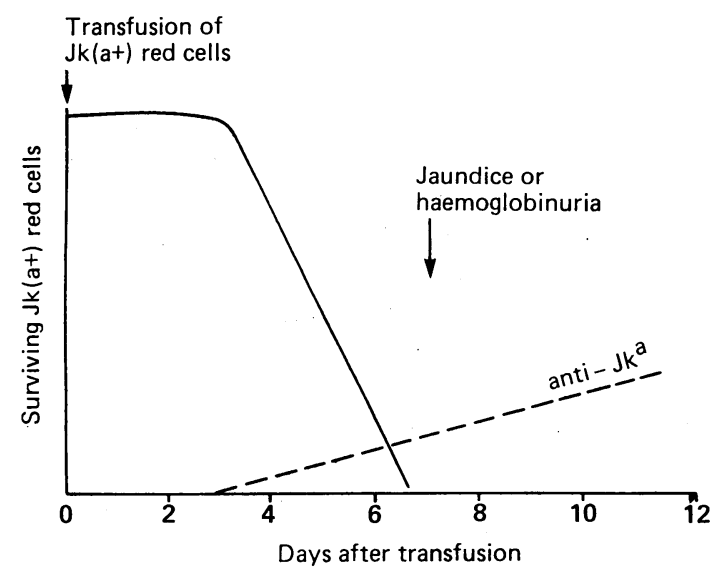

\section{Delayed haemolytic transfusion reactions}

These reactions occur in subjects who have been immunised to a foreign antigen by an earlier transfusion or a previous pregnancy but in whom the concentration of antibody to the foreign antigen is low so that it cannot be detected by the tests before the transfusion. After the current transfusion of red cells containing the same foreign antigen there is a secondary immune response, and after a few days the concentration of antibody has risen sufficiently to cause rapid destruction of those transfused red cells that contain the foreign antigen. The signs of a delayed haemolytic transfusion reaction are fever, a falling haemoglobin concentration, and jaundice or haemoglobinuria, usually about five to 10 days after transfusion.

The spegificities of the antibodies responsible for delayed haemolytic transfusion reactions are most often within the $\mathrm{Rh}$ system - that is, anti-c, anti-E, and so on - or in the Kidd (Jk) system, but they may have other specificities such as anti- $\mathrm{K}$.

Delayed haemolytic transfusion reactions occur after about one in 500 transfusions; alone they are seldom fatal, but they may have a serious adverse effect on a patient who is already gravely ill.

\section{Reactions to incompatible white cells}

Foreign leucocytes + leucocyte antibody

$\downarrow$

Engulfed by host monocytes

$\downarrow$

Release of pyrogen

$\downarrow$

FEVER

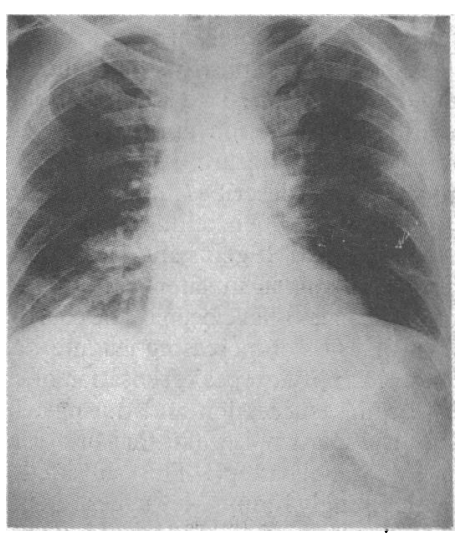

Chest radiograph of a patient who experienced a severe transfusion reaction as a result of potent leucoagglutinins in transfused plasma. There are numerous nodules, predominantly perihilar, and infiltration of the lower lung fields.

\section{Febrile reactions}

In patients whose plasma contains potent leucocyte antibodies the transfusion of whole blood or of blood components containing incompatible leucocytes may provoke severe reactions. The most common feature is fever, often preceded by shivering and beginning 30-60 minutes after the start of the transfusion; this is caused by the release of pyrogens from the recipient's granulocytes and monocytes. In some cases flushing of the face develops within five minutes of the start of the transfusion, presumably as a result of the release of the products of complement activation into the circulation.

Febrile reactions are quite common in patients who have previously been pregnant or have had transfusions. Most reactions are mild and can be dealt with by slowing the transfusion and giving aspirin. In patients who have had at least two severe febrile reactions blood depleted of white cells should be transfused - that is, blood that has either had the buffy coat removed or has been passed through a special filter.

\section{Pulmonary infiltrates}

If the donor's plasma contains potent leucoagglutinins incompatible with the recipient's granulocytes transfusion may cause a severe reaction characterised by chills, fever, a non-productive cough, and dyspnoea. A chest radiograph will show numerous nodules, predominantly perihilar, with infiltration of the lower lung fields. The donors are almost always multiparous women who have developed leucoagglutinins during pregnancy. 


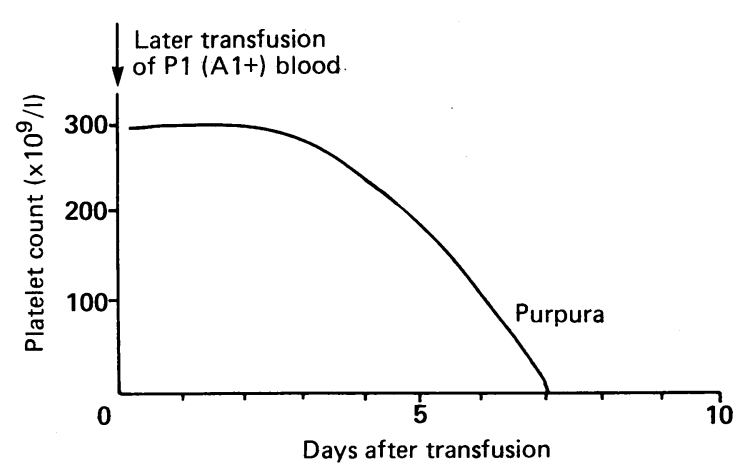

Reactions to plasma

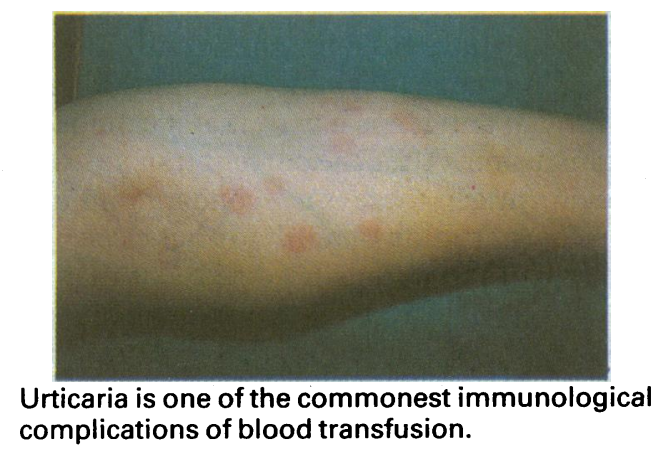

The chest radiograph is produced by kind permission of the department of radiology and the audiovisual department, St Mary's Hospital Medical School, and the picture of urticaria by kind permission of Dr Lionel Fry.

Marcela Contreras is director, North London Blood Transfusion Centre, and P L Mollison is professor emeritus of haematology, London University.
Although it is doubtful whether platelets themselves can cause febrile reactions, transfusions of platelet concentrates quite often do so because they contain contaminating leucocytes.

Platelets can cause a serious kind of delayed reaction known as "posttransfusion purpura." The patient has become sensitised to a foreign platelet antigen (most commonly $\mathrm{Pl}^{\mathrm{AI}}$ ), usually as a result of previous pregnancies but sometimes by transfusion. After a later transfusion of blood with platelets carrying this antigen a secondary response develops, and this leads (for somewhat obscure reasons) to destruction of the patient's own $\mathrm{Pl}(\mathrm{Al}-)$ platelets and severe thrombocytopenia. Although the incidence of $\mathrm{Pl}(\mathrm{Al}-)$ subjects among Europeans is 2 in 100 , post-transfusion purpura is rare. The best treatment is plasma exchange or large doses of immunoglobulin given intravenously.

The commonest adverse reaction to plasma (or any blood component containing plasma) is urticaria. The cause is presumably a reaction between some foreign protein (for example, from pollen or milk) present in the donor's plasma and a corresponding IgE antibody in the recipient's plasma. Urticaria is usually mild, but if it is severe it can be treated by slowing the transfusion and giving an antihistamine (for example, chlorpheniramine $10 \mathrm{mg}$ intravenously or intramuscularly). Patients who have developed urticaria after a previous transfusion may be given antihistamine orally before subsequent ones.

Rarely, severe anaphylactic reactions occur, and they are characterised by hypotension, substernal pain, dyspnoea, and gastrointestinal symptoms including abdominal cramps. These reactions are usually the result of a reaction between normal IgA in the donor's plasma and so called class specific anti-IgA.in the recipient's plasma; this antibody is found only in "aIgA" subjects, who are almost completely deficient in IgA $(<1 \mathrm{mg} / \mathrm{l}$ plasma); the incidence of aIgA subjects in the normal population is about 1 in 1000 . Severe anaphylactic reactions should be treated by stopping the transfusion and giving adrenaline $0 \cdot 5-1 \mathrm{mg}$ subcutaneously or intramuscularly and hydrocortisone $100-200 \mathrm{mg}$ intravenously. Transfusion reactions in patients with anti-IgA in their plasma can be prevented by using IgA deficient donors or, if unavailable, well washed red cells.

\section{MATERIA PARAMEDICA}

\section{The planes of laughter}

Beatrice Lillie died this year. Previously I knew only that she was on the stage and was famous. From her obituary notices I learnt something of the talent that had made her so very special.

For several years I had a patient who seems to have been similar to Beatrice Lillie. Her first visit was almost concluded when I most unfortunately yawned-at 10 am. She said, "I hope I'm not keeping you up," raised her eyebrows, and smiled slightly. It doesn't sound much but it sank me in gales of laughter. When I looked to be recovering she produced another expression and another smile and I relapsed. This went on for some time, perhaps two minutes, when she desisted, said goodbye, and left me a mass of conditioned reflexes. She came to see me at most once or twice a year. I failed to recognise her every time and the visit would be almost over, when I would find that she was looking at me expectantly, and I would realise who it was. She would make some slight remark or perhaps sweep the floor with her eyes, look at me, her expression would change, and she would smile her gentle devastating smile. I would collapse into laughter, and events proceeded as before. Her expressions might be of approval or reproof, charm or teasing, modesty or mystery, always ironic and fleeting, and as a shared joke. She was unassuming and quiet in dress, in voice and in manner. The basis of this rare talent is uncertain. I think she had very mobile features which reflected her thoughts, combined with an acute sense of amusement. In effect, she thought her thoughts and her expressions changed accordingly.

There could perhaps be four planes of laughter; a first plane of induction; a second plane of progressive laughter, of increasing depth but still intermittent; a third plane of being helpless with laughter or fully laughterised. This plane is unquestionably one of the great joys of life, and vast amounts of time, money, effort, conversation, and especially drink are expended in endless search for this elusive rapture.

The fourth plane is not funny. Dickens describes in the Pickwick Papers how Mr Weller senior passed into this when telling Sam how he was engaged in putting it across the Reverend Stiggins and had paroxysms of chuckles ending in partial suffocation; and again later by a hoarse internal rumbling and violent swelling of the face. I have been in the fourth plane a few times since my mid-50s. It consisted of increasing laughter, a tearing pain across the front of the chest, inability to speak, sensation of choking, and inability to breathe, all in quick succession and during which the laughter was replaced by a cyclical chest noise like that of a car engine being turned over by a rapidly failing battery. This subsided when I realised that the joke was in truth killingly funny. My suggestion is that the central feature of this is laryngeal spasm. It would be a simple matter to decide the point, were it not for the problem of keeping the subject sufficiently amused.

GEOFFREY HARRIS 